\title{
DOUTRINA
}

\section{Breve Apanhado Sobre a História da Advocacia em Roma}

\author{
Alexandre Augusto de Castro Correia \\ Titular de Direito Romano da Faculdade \\ de Direito da USP
}

Como arte e profissão a advocacia tem longa e interessante história e suas origens ocidentais devem buscar-se em Atenas sob Péricles e sobretudo em Roma, berço da ciência do Direito.

A bibliografia sobre o assunto é abundantíssima sendo, por outro lado, impossivel atingir todos os aspectos da matéria no curto espaço dum artigo. Desejamos, por isso, mencionar, desde logo, duas monografias históricas, uma atual «Advocatus Romanus», de autoria do Prof. argentino, Kornem Zoltan Méhesz, professor titular de D. Romano na Universidade Nacional do Nordeste ( $1^{\circ}$ vol. Buenos Aires, Zarahá, editor - 1971) e outra, já mais antiga, porém mais completa em certo sentido e escrita por Grellet-Dumazeau «Le Barreau Romain - Recherches et études sur le Barreau de Rome, depuis son origine jusqu'à Justinien et particulièrement au temps de Ciceron» (1? vol. Paris, 1858). Ambos os trabalhos, de agradável leitura, possuem, entre outros, o mérito de se basearem nas fontes de modo a se ter ótimo perfil histórico da advocacia romana, cujas vicissitudes são ainda as de nossos dias.

Abordaremos, tão só, os aspectos mais interessantes da instituição em Roma, a saber:

1. Origens da advocacia romana

2. Denominações diversas dos advogados

3. Os advogados como ordem ou corporação

4. O advogado em audiência

5. Moralidade profissional dos advogados

6. Seus honorários

7. Principais figuras de advogados romanos 


\section{ORIGENS DA ADVOCACIA ROMANA}

O grande acontecimento, como se sabe, marcando o início da separação entre Religião e Direito foi entre os romanos a promulgação da Lei das XII Tábuas em 450 mais ou menos A.C. Este monumento legislativo torna também possível o nascimento da advocacia e dos juristas, propriamente ditos, enquanto simples cidadãos, podendo opinar sobre o «Jus» sem pertencerem mais ao Colégio Sacerdotal dos Pontífices, corporação religiosa detentora até às XII T. do monopólio do Direito chamado «Fas» por confundir-se com a religião. A promulgação da lei, vitória política da plebe, em sua luta secular com o patriciado, originou o aparecimento dos primeiros juristas leigos autorizados não só a opinar sobre o sentido exato dos preceitos codificados como também a pleitear causas. Tito Lívio relata-nos o célebre processo de Virginia, injustamente acusada, por um dos decênsivos, de ser escrava. Ela comparece a juízo acompanhada pelo tio, Numitor, e pelo noivo Icilio.

O primeiro pede dois dias de prazo para poder prevenir do processo ao pai da acusada e reclama a guarda provisória desta, mediante caução. Fundamenta o pedido em texto expresso das XII Tábuas o qual afirma: durante o processo e até sentença definitiva o réu tem direito à liberdade, «vindiciae sunt decundum libertatem», e dessa forma o patrício Apio, autor da prisão ilegal da acusada, viu-se punido pela aplicação da lei de sua própria autoria.

Trata-se no caso do que poderíamos qualificar sem erro de «habeas corpus» contra prisão ilegal.

Numitor, por outro lado, aparece como autêntico advogado.

Aliás, o emprego do termo advogado, feito agora, leva-nos ao tópico seguinte sobre as:

\section{DENOMINAC̄̃ES DIVERSAS DOS ADVOGADOS}

Os romanos muito cedo distinguiram entre o jurisconsulto e o advogado, mais ou menos como os ingleses distinguem entre o «barrister» e o «attorney-at-law». Em conhecido texto do Digesto sobre «A Origem do Direito, de todos os magistrados e da sucessão dos jurisconsultos» - («prudentes»).

Pompônio informa: D. 1,2,2,35) «Vários grandes homens dedicaram-se ao estudo da jurisprudência; «não se conhece ninguém professando esta ciência publicamente antes de Tibério Coruncânio», cônsul 474 a.C., primeiro plebeu elevado ao cargo de grande pontífice e o primeiro também a «publice profiteri» (D. 1,2,2,35.38), isto é, a dar pareceres em público, perante ouvintes que podiam tomar notas, adquirindo, assim, progressivamente, conhecimento geral da «jurisprudentia» ou ciência do direito. 
O jurista romano dá, pois, opiniões motivadas mas não patrocina obrigatoriamente em Juízo, embora possa fazê-lo. Esta última tarefa, inclusive pelos dons oratórios exigidos, era confiada ao «advocatus». Cicero, em texto conhecido, afirma que todo bom jurista deva ser «ad agendum, ad cavendum et ad respondendum peritus». A primeira função, «agere», consiste não propriamente em patrocinar mas em orientar o causídico no tocante às formas dos atos processuais. Assim, o jurista seria o homem d'estudo, de gabinete, diríamos, enquanto o homem da prática seria o advogado, embora distinção não deva ser tomada ao pé da letra pois jamais houve em Roma a separação rigorosa, observada entre teoria e prática do direito, tal como se nota hoje na Inglaterra, na Alemanha ou na França.

«Patronus» é designação mais antiga que «advocatus» e remonta ao período aristocrático da profissão quando só o patrício, membro de alguma «gens» tinha acesso ao direito. Já, porém, no processo de Virgínia seus parentes e amigos são chamados em defesa («vocati ad», «ad - vocati») da acusada a qual tem «advocati» e não mais «patroni» (Tito Lívio, III, 5 e 44).

No tempo de Cícero o «patronus» comparecia a Juízo, defendendo a causa, enquanto o «advocatus» se encarregava de reunir para o primeiro os meios de prova, adiantando provisão das despesas. Vemos, assim, o jovem Messala zeloso advogado de Roscio de America, cujo, «patronus» foi Cícero. Chamavam-se também «advocati» as pessoas influentes comparecendo a uma audiência a fim de, pela sua presença, demonstrarem o interesse ou a simpatia por um dos litigantes; constituíam, assim, o público.

Já sob Augusto «advocatus» torna-se sinônimo de «patronus»e vemos o primeiro termo perder o primitivo sentido: «postulare advocationem» é, então, pedir licença para defender um acusado. A função do advogado chamou-se «officium», «munus advocationis».

Usava-se, também, o termo em sentido pejorativo quando se dizia «litem instruere advocatione» para significar as manobras fraudulentas junto a um advogado a fim de obter a condenação dum inocente ou a absolvição dum culpado.

Quintiliano, entusiasta da linguagem de Cícero, prefere ainda «patronus» embora «advocatus» fosse termo mais usado em seu tempo.

Plínio, o Moço, distingue entre «advocatio» e «consilium» para designar o advogado por assim dizer militante pelo primeiro vocábulo e o orientador e autor de pareceres pelo segundo: «Multos advocatione, plures consilio juvat».

A palavra «causidicus», usada apenas duas vezes por Cícero, começa a ser empregada a partir de Domiciano, significando como é óbvio quem pleiteia uma causa. Quintiliano informa-nos que se tratava por «causidicus» ao advogado medíocre, capaz, no entanto, de defender os interesses do litigante. Poetas como Juvenal e Marcial empregam quase sempre o termo em sentido pejorativo. 
A partir dos séculos II e III d.C. as antigas distinções de sentido entre «patronus», «advocatus» e «causidicus» se pagam e Ulpiano define os «advocati» (D. 50,13,1,11) como «todos quantos se dão ao estudo das leis e pleiteiam as causas nas quais elas se aplicam». Os imperadores Valentiniano e Valente reunem como sinônimos as três designações: «Quem quer ser causídico não seja advogado e juiz na mesma causa, pois deve haver alguma diferença entre árbitros $\mathrm{e}$ patronos» (C. 2,6,6).

Os advogados não podendo pleitear sem toga chamaram-se «togati» e nas constituições dos séculos V e VI d.C. lê-se freqüentemente: «togati», «consortium», «ordo», «collegium togatorum».

Outros nomes eram usados para denegrir certa classe de advogados: «rabulae» (Cícero) de «rabies», raiva ou de «radere aures», raspar os ouvidos do ouvinte, ou ainda, de «ravis», voz rouca: «latratores» («latidores»), «clamatores», «proclamatores», (gritadores).

Tais nomes aplicavam-se indistintamente aos advogados assinalando-se pela ignorância, descaramento e voracidade.

Outras denominações identificaram menos os advogados, propriamente ditos, do que certos indivíduos desempenhando funções especiais em uso no tribunal. Referimo-nos aos «leguleii», «formularii», «monitores», «moratores» e «cognitores».

«Leguleii» e «formularii» eram jurisconsultos de segunda ordem, ajudando os litigantes e mesmo os advogados jejunos em direito: apegavam-se ao estudo da letra da lei e das formas do processo. Define-os Cícero assim: «cautos e agudos, pregoeiros das ações, cantores de fórmulas, zoilos».

Estes «minores advocati» recrutavam-se igualmente dentre os advogados vencidos no Tribunal ou tendo recuado diante dos trabalhos exigidos pela oratória; eram os práticos, chamados «pragmatikói» pelos gregos.

$\mathrm{O}$ «monitor» era leguleio assistindo aos advogados nas audiências, sugerindo-lhes de improviso meios jurídicos ou respostas às questões apresentadas pelo adversário. Atuava sobretudo na altercação, espécie de defesa dialogada no tocante à discussão das provas e no decorrer da qual o advogado, pouco versado em direito, se expunha aos riscos mais graves.

No exercício dessas funções o «monitor» chamava-se, também, «ministrador» pois «ministrava armas aos litigantes» (Quintiliano). Às vezes o monitor figurava sozinho na altercação quando o advogado temesse comprometer-se nos debates; então, o primeiro podia ser mais útil à parte do que o segundo.

O «monitor» desempenhava, também, função análoga ao do ponto no teatro: colccava-se atrás do advogado com um caderno na mão e socorria aquele em seus lapsos de memória. 
«Morator» (o que «retarda») era advogado de última categoria, tomando a palavra enquanto o advogado principal descansava e às vezes, também, para protelar a causa.

«Cognitor», finalmente, era espécie de mandatário substituindo a parte como autora ou ré: era o «dominus litis» praticando em seu próprio nome os atos processuais.

Diferia do «procurator», sobretudo enquanto este podia ser constituído sem formalidade especial e mesmo à revelia do adversário.

\section{OS ADVOGADOS COMO ORDEM OU CORPORAC̣ÃO}

Durante o período da República a profissão do advogado foi submetida a condições d'exercício, a impedimentos, a medidas disciplinares mostrando a existência senão já de ordem propriamente dita pelo menos a de alguma coisa com individualidade no seio do Estado. No tempo de Catão, o Antigo, a lei Cincia proíbe a cobrança de honorários; no tempo de Cícero a defesa por advogado é obrigatória mediante nomeação feita de ofício pelo magistrado: Augusto, Cláudio, Nero e Trajano confirmam, sucessivamente, ou modificam a lei Cincia. $\mathrm{O}$ tribunal dos centumviros admite que pleiteie perante ele, pela primeira vez, só o apresentado por pessoa ilustre. O caráter, todavia indicativo da existência de pessoa jurídica, só se torna evidente a partir de Alexandre Severo e seus sucessores.

Ulpiano informa-nos que ninguém pode postular sem autorização do magistrado, proibição implicando a existência de organização. Sob os imperadores Teodósio e Valentiniano, Marciano, Leão, Justino e Justiniano a corporação dos advogados é minuciosamente regulamentada. Chama-se «collegium», «ordo», «consortium», «corpus», «toga», «advocatio», «matricula».

Autorizados por permissão expressa ao exercício de seu ministério, os advogados eram inscritos num quadro por ordem de antigüidade; seu número era limitado; eram submetidos a exames e a período de estágio; gozavam de privilégio especial; podiam ser suspensos e interditados; junto a certas jurisdições superiores, finalmente, a profissão de advogado constituía verdadeiro monopólio.

\section{MULHERES ADVOGADAS}

Nunca foi proibido às mulheres advogarem em causa própria, embora, segundo Plutarco, uma lei de Numa vedasse-lhes falar, mesmo das coisas mais graves, sem a presença dos maridos.

A história conserva a lembrança de Amésia Sentira, dama romana defendendo-se de acusação dirigida contra ela durante a República; sua defesa foi notável pelo método, nitidez e força, resultando em absolvição quase unânime; e como escondesse coração de homem sob traços femininos apelidaram-na, diz Valéria Maximo, de Andrógina. 
Caia Afrania ou Carfania, mulher do senador Bucco adquiriu horrivel fama, devido à sua paixão pela chicana. Demandista, Carfania defendia-se pessoalmente escandalizando o público, tanto pela injustiça das pretensões, quanto pela impudência das palavras. Seu nome ficou na linguagem corrente dos romanos para significar mulher despudorada e rabujenta. Morreu ela em 48 a.C., durante o consulado de César e Valério Maximo, cronista do tempo, acha preferivel consignar a data do desaparecimento de semelhante monstro do que a de seu nascimento. Carfania, devido ao comportamento escandaloso, foi a causa ocasional da disposição do edito do pretor proibindo as mulheres de advogarem. O texto de Ulpiano, conservado no Digesto, é expressivo (D. 3,1,1,5): «A proibição provém do caso de Carfania, mulher muito descarada, a qual atuando sem pudor como advogada e importunando o magistrado deu causa ao edito».

Hortênsia, pelo contrário, filha do grande orador e advogado Hortênsio, deixou fama digna do pai: cinco anos depois da morte de Carfania apresentou-se ela em defesa das damas romanas atingidas por imposto excessivo. Seu discurso obteve retumbante êxito e a taxa foi consideravelmente reduzida. A proibição do edito já existia, mas Hortênsia falava em causa própria e o pretor só vedara às mulheres «postulare pro aliis».

Sob Domiciano mostra-nos Juvenal as mulheres suscitando processos, compondo memórias para os advogados e inscrevendo-se como acusadoras, embora sem pleitearem pessoalmente.

«Quase todos os processos se instauram a seus pedidos. Quando não esteja defendendo, Manilia acusa; o memorial é escrito por sua mão; seus libelos podem fornecer exórdio e defesa a Celso». (VI, 238-241).

\section{O ADVOGADO EM AUDIÊNCIA}

Toda a retórica e teatralidade características da profissão manifestam-se tipicamente nas audiências, sobretudo criminais, tanto em Roma, quanto hoje. Mesmo, porém, em assuntos cíveis não deixa de haver drama favorecido pela predominante oralidade do processo romano. Acompanhemos, pois, guiados pelos autores, o «advocatus romanus» atuando como defensor.

Desde o nascer do sol os clientes se postam no vestíbulo da casa do profissional, acompanhando-o em cortejo em direção ao «Forum», sendo que os mais solícitos carregam-lhe as pastas contendo os processos.

As audiências mais importantes eram à tarde e o público, muito antes do início, já lotava o auditório, disposto circularmente de modo a Juízes e advogados abrirem caminho com dificuldade. Havia tribunas espaçosas ocupadas por homens e mulheres e via-se melhor do que se ouvia. 
Nas questões criminais a sede curul do pretor colocava-se sobre um estrado elevado («tribunal») diante de haste («hasta») e gládio, símbolos do «imperium» e da força. Mais abaixo ficavam os assentos dos Juízes («subsellia») dispostos em semicírculo.

O acusado e seus defensores sentavam-se à esquerda do magistrado; os acusadores ocupavam o lado oposto.

Os assentos dos advogados chamavam-se também «subsellia».

O orador tomava lugar na barra do tribunal acompanhado de secretário e do jurisconsulto o qual dera parecer sobre o caso. A seu lado, sentavam-se, também, parentes e amigos da parte.

Nas questões cíveis, o juiz dava a palavra ao advogado e nas questões criminais fazia-o o porteiro ou o pretor mesmo quando presente. $O$ advogado falava de pé não lhe sendo, entretanto, vedado falar sentado o que fazia nas questões menores ou perante juízes de ordem inferior.

Precisando fazer-se ouvir dum público numeroso, atingindo multidão impaciente, o orador habituara-se praticamente a gritar. Dessa forma, mesmo quando as audiências passaram a se realizar nas basílicas o hábito se conservou e segundo Quintiliano, certo advogado, falando numa sala, era ouvido e aplaudido em três salas vizinhas. A voz, por conseguinte, empostada e amplificada graças a penosos exercícios do orador substitua, até certo ponto, os modernos microfones.

Alguns advogados, por precaução, falavam assistidos por um ponto dando por isso motivo às zombarias dos colegas. A maioria, porém, falava de modo semi-improvisado, tendo à mão notas mais ou menos extensas consultadas quando necessário.

Falando, o orador caminhava às vezes pelo espaço livre entre a barra do tribunal e o assento dos Juízes. Quintiliano autorizava esta espécie de passeio («ambulatio») somente o tempo necessário para o causídico receber os aplausos do auditório. Cícero, entretanto, louvava Crasso por este nunca se ter afastado do lugar.

Certos advogados avançavam até aos pés dos Juízes e, não devendo dar-lhes as costas, afastavam-se, recuando, de frente para eles. Outros avançavam até ao banco da parte contrária o que motivou o pedido humorístico de Severo, reclamando uma grade entre ele e seu opositor.

A gesticulação, naturalmente, enquanto meio de se fazer compreender pelo público, era objeto d'estudo especial por parte dos oradores. Como, porém, a mímica especial era difícil não era raro verem-se oradores, mesmo de categoria, elevando os braços verticalmente, estendendo-os horizontalmente, em todo o comprimento ou mesmo movendo-os em todos os sentidos, com violência inquietante para os vizinhos. 
Outros, agitavam a mão de cima para baixo e de baixo para cima, com os dedos abertos e a palma de lado, como para cortar alguma coisa; ou então lançavam-na para trás, à maneira de quem atira uma pedra por cima da cabeça ou ainda serviam-se dela para enxugar o rosto, esfregando-a aberta do queixo até à testa. Alguns estalavam os dedos, batiam no peito ou mugiam, levantando os olhos para o céu.

Bater no rosto e na coxa era gesto muito usado; Crasso era mestre em bater o pé no chão, tirando, por outro lado, grande partido do indicador direito.

Curião, pai, balançava-se falando, da direita para a esquerda e vice-versa como se obedecesse ao jogo dum navio e por isso um de seus ouvintes perguntou quem era aquele orador falando como se estivesse numa barca.

Hortênsio foi o orador mais notado pela perfeição do gesto, sendo nesse sentido verdadeiro artista, a ponto, escreve Valério Maximo, de não se poder saber se todos quantos acorriam às suas defesas preferissem antes vê-lo que ouvi-lo. Esopo e Rócio, os dois maiores atores da época, sentavam-se a seu lado, a fim de lhe estudarem a mímica.

Tribunal tão célebre não escapou, entretanto, às pequenas misérias, infaliveis nas defesas: quando a memória ou as idéias lhes faltavam viam-se os advogados tossirem ou fazerem as contorsões de pessoas sufocadas pelo catarro; outros enfureciam-se contra si próprios ao gaguejarem na pronúncia duma palavra. Curião, ao qual aludimos há pouco, pleiteando contra Cícero, esqueceu completamente o discurso, incapaz de pronunciar uma só frase. .

Quando fatigado, bebia o orador um copo d'água; aliás, podia, também, interromper a audiência para comer, costume sobrevivendo, ainda, ao tempo de Quintiliano, que aliás o reprova.

Durante a defesa o adversário distraía-se com os vizinhos, dava de ombros ou balançava a cabeça em sinal de desaprovação, tomava notas, escrevia bilhetes e mandava emissários às pessoas cuja presença considerasse útil. Às vezes, interrompia para pedir explicações ou responder a objeções; nesses momentos tratava o orador com familiaridade.

Este interrompia-se a si próprio para fazer ler documentos ou para dar aos Juízes tempo d'examiná-los; às vezes quem interrompia era o próprio Juiz.

Querendo manifestar aprovação o povo exclamava: «Bene! praeclare! belle! festive! non potest melius!».

Às vezes os Juízes misturavam suas felicitações às do público. Quando, porém, o advogado era fastidioso os presentes bocejavam, conversavam com os vizinhos, pediam a hora, passeavam pelo recinto e solicitavam mesmo ao presidente a suspensão da audiência. 
A divisão dos discursos era rigorosamente observada, sobretudo por influência da filosofia grega: exórdio, narração, confirmação, refutação e peroração. Nesta o recurso do orador a elementos dramáticos chegava ao auge e todos os artifícios se empregavam para comover os Juízes.

Um tomava nos braços a criança, passeando-a pelo tribunal; outro exibia as chagas purulentas do cliente; este, vendo o acusador brandir gládio ensangüentado fugia, simulando espanto, para voltar com o rosto semioculto pela tofa e perguntando se o homicida tinha desaparecido; aquele exibia ossos e roupas manchadas de sangue. Alguns penduravam sobre a estátua de Júpiter quadro representando as principais circunstâncias do crime.

Certo advogado pleiteava os direitos duma jovem e a parte contrária recusava-se a reconhecê-la como sua irmã. $\mathrm{Na}$ peroração o orador aproxima a cliente do irmão desnaturado e simula jogá-la nos braços deste, o qual, porém, abandonara furtivamente a sala, forçando o advogado a segurar o desastrado fardo. Outro, defendendo certa viúva, colocara atrás de si agentes encarregados de exibir o retrato do defunto. Ignorando o momento da peroração os comprades erguiam a tela, sempre que os olhares do orador se voltavam para eles e isto já excitava a hilariedade do auditório; outra foi, porém, a impressão quando o retrato, inteiramente descoberto, mostrou ao público velho caquético e disforme.

Até aqui, o grotesco e cômico das encenações. Há, porém o autenticamente dramático. Uma das perorações mais célebres do fôro romano foi a de Antônio, defensor de Manio Aquilio, acusado de concussão. O velho magistrado, antigo cônsul, estava para ser condenado quando Antônio fê-lo erguer-se do banco, rasgou-lhe a túnica e mostrou aos assistentes atônitos as várias cicatrizes testemunhando os ferimentos sofridos pelo digno cidadão a serviço da república. Os Juízes, emocionados até às lágrimas, como o próprio advogado, não puderam resistir à força do sentimento e o acusado foi absolvido.

Graças a artifício do mesmo gênero Galba conseguiu escapar à condenação iminente: fez comparecer ao tribunal os próprios filhos declarando solenemente que antes de deixá-los queria entregá-los à tutela do povo romano.

Terminada a defesa, clientes e amigos do advogado rodeavam-no para cumprimentá-lo. Caso entusiasmado, o público o aclamava, embora tal modo ruidoso de aprovar fosse considerado inconveniente, sobretudo quando os debates não se realizassem em praça pública. O abuso começa a partir de Nero quando apareceram verdadeiros empresários de «Claques», recrutando gente humilde que mediante retribuição módica se dispunha a aplausos dirigidos por um chefe o «mesíchoros», colocado no centro da falange: abertas as portas os mercenários invadiam os lugares e a um sinal do chefe, começavam os murmúrios de aprovação, os ruídos com os pés, as aprovações 
laudatórias, os gritos de admiração. Plínio, o Moço, relata e lamenta este estado de coisas, próprio dum periodo no qual a eloqüência forense começa a decair.

O advogado Domicio Afer, bom orador do tempo de Nero e Cláudio, defendia certa ocasião perante o tribunal dos Centumviros quando ouviu clamores imoderados vindos de sala vizinha; parou e o silêncio se restabeleceu; retomando a palavra ouve novos clamores; nova interrupção seguida de novo silêncio, permitindo a Domicio continuar o discurso. Interrompido pela terceira vez, ele pergunta qual é o advogado pleiteando na outra sala. Respondem-lhe: é Licinio «Centumviros», exclama então Domicio, «a oratória acabou!»

Omitindo por falta de tempo outros assuntos passo à questão da:

\section{MORALIDADE PROFISSIONAL DOS ADVOGADOS}

Catão definiu o orador como «Vir bonus dicendi peritus», o homem honesto versado na arte de falar bem. E Quintiliano considera impossível seja alguém orador sem ser, ao mesmo tempo, homem de bem, pois, a oratória visa persuadir e convencer o auditório a respeito da superioridade da virtude. Tal conceito aplica-se, sobretudo, ao advogado no sentido da oratória perfeita ser impossível sem a virtude.

Pois, como poderia o homem desonesto tratar convenientemente da Justiça? Em igualdade de condições de saber e talento, o orador honesto, diz Quintiliano, suplanta o desonesto.

A este raciocínio se pode objetar com o exemplo de Demóstenes, o qual não teve reputação de homem virtuoso lembrando-se, também, as severas críticas dos contemporâneos aos costumes de Cícero. E, na prática, os imperativos da acusação ou da defesa colocavam mesmo os grandes advogados romanos bem abaixo do ideal preconizado pelos dois escritores citados.

Tradição proveniente do patronato mandava o advogado pôr sua palavra a serviço só dos acusados: Cícero justifica-se enquanto acusador de Verres alegando que na verdade defendia os Sicilianos, expoliados pelo acusado. Segundo Cícero o advogado só uma vez na vida ou muito raramente deve aceitar o papel de acusador. E, no entanto, pregava: «Acusatores multos esse in civitate utile est ut metu continetur audacia.»

Ele mesmo acusou só duas vezes, enquanto Catão, o Antigo, apresentou grande número de acusações sendo por sua vez acusado mais de cinqüenta vezes. $\mathrm{E}$ os homens mais notáveis não temiam inscrever-se como acusadores quando julgassem necessário fazê-lo em defesa do interesse público. A acusação tornou-se imoral em Roma (como sucede em toda parte) quando inspirada pela inveja, por ódios particulares ou pela avidez: o próprio Catão teria cedido a esses sentimentos inferiores ao acusar Cipião, o Africano, o herói vencedor de 
Aníbal e o irmão daquele, Lúcio Cipião. Durante o Império o principal móvel das acusações foi a cupidez e os acusadores enriqueceram à custa da fortuna dos condenados de modo ao nome de acusador tornar-se sinônimo de assassino.

As acusações deram origem a abuso tão freqüente quanto escandaloso a partir de certa época: a prevaricação, consistente em apresentar acusações fraudulentas para ocultar o verdadeiro culpado ou então em se deixar subornar pelo acusado durante o processo. Cícero imputou a Cecílio, antigo questor de Verres, o querer acusar ao governador corrupto a fim de preparar melhor a impunidade deste.

Os «subscriptores» ou acusadores adjuntos fiscalizavam o acusador titular; mas, as pessoas estranhas ao processo não consideravam suficiente tal garantia, pois também, os «subscriptores» eram subornáveis. Colocaram-se por isso, junto ao acusador vigilantes especiais («custodes») incumbidos de espionar todos os atos do primeiro, seguindo-o nas províncias por onde andasse em busca de provas, contando e verificando os documentos para certeza de que nada fora sonegado.

Nenhuma dessas providências, entretanto, pouco honrosas para o Tribunal, puderam impedir a corrupção e não impediram Clódio de vender seu silêncio a Catilina a quem o primeiro acusara de peculato.

Durante o Império a prevaricação adquiriu aspecto novo, abalando profundamente a moral pública. A maioria, com efeito, das acusações era exigida pelo príncipe, ou apresentada, a fim de captar-lhe os favores ou de lhe lisonjear os ressentimentos ou caprichos. Desapareceram, então, os conluios do acusador como o acusado para, a peso de ouro, subtraírem este último a condenação certa. Em compensação surgiu a prática inaudita do defensor aceitar suborno para abandonar o acusado!

«O príncipe» escreve Tácito, «chamando a si todo o poder legislativo e todas as magistraturas abrira a porta a esse banditismo e de tudo quanto se vendia publicamente em Roma nada se vendia com tanta abundância quanto a perfídia dos advogados». A venalidade dos advogados, tornada em certo sentido proverbial, constituiu fonte inesgotável na qual se abeberou a sátira dos poetas como Juvenal e Marcial.

A legislação de Justiniano persegue, ainda, (D. 47,15, «Da prevaricação», 1, pr. Ulpiano, livro 6 sobre o Editor do pretor), a prevaricação «Prevaricador é quem, fingindo interessar-se por um, trai, entretanto, sua causa, ajudando o adversário. Segundo Labeão o nome provém duma variedade de combates: pois quem os provoca prevarica ao favorecer a um mais que a outro.

$\S 1^{\circ}$ - Prevaricador, propriamente dito, é aquele que acusa alguém em juízo público. Aliás, o advogado não é, propriamente, prevaricador. Que será dele se tiver prevaricado em juízo público 
ou privado, isto é, se tiver traído a causa? Costuma ser punido em processo extraordinário.»

Afastemo-nos, porém, dessas ignomínias e remontemos a épocas mais distantes, quando o tribunal tinha pelo menos algumas virtudes: durante toda a República não se conhecem casos de prevaricação. Só nos últimos tempos desse longo período começou o advogado a procurar no exercício da profissão o meio de enriquecimento rápido permanecendo, porém, sempre fiel aos interesses do cliente.

Em teoria o devotamento era levado a extremos. Cícero escreve: «se prometeste defender alguém e durante o processo um teu filho vai gravemente enfermo não faltarás, ausentando-te, aos deveres de tua profissão». Caio Aurélio Cotta, disputando com Hortêncio os favores do público, não era tão rigorista, dizendo: «Aceitando-se só as boas causas não se enche a casa de clientes»!

Eis o móvel mais poderoso da fidelidade chamada «fides patroni», a fé do advogado. Tal sentimento originava os mais escandalosos abusos. Apesar de dizer que o homem de bem só deve, em princípio, aceitar as causas justas, Quintiliano permite ao advogado dissimular a verdade em certos casos: quando, por exemplo, é mais útil para a sociedade absolver em vez de condenar ou quando ação boa em si mesma deva ser reprimida pelo juiz, caso não se consiga persuadí-lo de que a ação não foi praticada: assim, Cícero mandou executar sumariamente os cúmplices de Catilina praticando ação justa, mas ilegal, que lhe valeu, aliás, o exílio em conseqüência de acusação apresentada contra ele por Clódio, político romano dos mais corruptos.

A verdade real, em tais casos, é substituída, por verdade processual ou formal se quisermos; em outras palavras a ilegalidade às vezes deve ser defendida como justa em vista de fim social relevante, merecendo defesa a qualquer preço. Semelhante concepção foi sempre aceita na antigüidade como representando moralidade verdadeira.

Defendendo a verossimilhança como a verdade do advogado Cícero invoca a autoridade do filósofo estóico Panécio ( De off.», П, 14). $\mathrm{Na}$ prática, entretanto, os advogados foram mais longe caindo como os sofistas da Atenas de Péricles em autêntico cepticismo.

Haveria processos mais justos do que os dos Siciliano contra Verres? Este, entretanto, era poderoso, rico e audacioso e Hortênsio não se pejou de praticar toda a sorte de manobras a fim de furtar o culpado ao castigo merecido. Tentou corromper, a peso de ouro, os deputados sicilianos; usou da autoridade adquirida a fim de afastar Cícero cuja energia e talento lhe causavam temor. Frustrada a tentativa Hortênsio procurou intimidar os juízes e recorreu a todos os meios protelatórios a fim de retardar os debates até a posse do novo pretor, mais favorável a seu cliente. Cícero precisou de toda a coragem, energia e tenacidade para vencer tais obstáculos.

Hortênsio fez ainda mais noutro processo: comprou os votos da maioria, chegando ao ponto de distribuir aos juízes subornados tá- 
buinhas de voto de cor especial a fim de, após o julgamento, certificar-se do cumprimento do ajuste.

Ninguém se envergonhava de defender causas opostas: durante as Verrinas, Cícero profligara certo julgamento proferido contra uma parte sob a presidência de Junio. A decisão, assinalada como produto monstruoso de fraude e corrupção, foi reabilitada pelo mesmo Cícero quando defendeu Cluêncio, seu cliente, acusado d'envenenamento. O causídico se gabou de ter obscurecido o caso tão bem a ponto de confundir inteiramente os juízes! Esta situação falsa do advogado romano dependeu em grande parte das instituições e das circunstâncias.

Em todos os governos populares, nos quais as magistraturas são eletivas, a ambição é sempre dominante nos tribunais: quando, no fórum, ecoavam as acusações de cabala, concussão e peculato dirigidas contra as personalidades mais poderosas da República não havia advogado eminente cuja conduta profissional não fosse determinada por considerações de candidatura pessoal.

Quando Cícero disputou o consulado Cecílio, tio de Ãtico, amigo intimo do orador, pediu a Cícero o patrocínio em processo civil no qual se tratava de anular certa venda feita em fraude de credores; Cícero preferiu romper com Cecílio, incorrendo no desagrado por parte de Ático, a aceitar a causa; Satrio, o autor da fraude, votaria por ele e além disso era ligado a Domicio, coluna mestra de sua eleição; finalmente, o candidato precisava fazer novos amigos!

A moralidade dos advogados, tão comprometida em Roma não podia ser melhor nas províncias, invadidas por eles, em busca de fortuna rápida.

Vários historiadores dão testemunho dos implacáveis ódios suscitados pelos causídicos da metrópole, devido à sua voracidade e espírito de chicana: depois do massacre das legiões de Varo, os Germanos foram impiedosos. Vazaram os olhos de certos profissionais, decaparam as mãos de outros. Um deles teve a língua cortada e a boca costurada.

O autor da mutilação exclamou, depois «víbora, para afinal de sibilar!» $O$ aviltamento chegou ao auge sob Calígula e seus sucessores. Não conseguindo o príncipe tender às despesas de seus prazeres e aos gastos destinados a manter a subserviência dos cortesãos, bem como a fidelidade das legiões e as aclamações da população, precisou de acusadores hábeis e escolheu-os dentre os advogados.

Os profissionais mais notáveis, «lucrosae et sanguinantis eloquentiae» prestaram-se ao abominável tráfico e graças a seu ministério, horrivelmente desviado de sua finalidade gloriosa, pereceram sob Cláudio trinta senadores, trezentos e quinze cavaleiros e multidão de simples cidadãos. A ciência dos jurisconsultos ilustrou o reino de Adriano e de alguns de seus sucessores; mas, a darmos crédito a 
Amiano Marcelino, o aviltamento do tribunal nunca ultrapassou o da segunda metade do IV século.

Marcelino divide em quatro espécies os advogados nômades, cercando as casas dos ricos, atrás de todos os processos, mais solertes em farejá-los a fim de levá-los para seus canis, do que os cães de Sparta e Creta. O quadro sinistro apresentado pelo autor é exagerado. Aliás, ele foi obrigado a abandonar a cidade de Antioquia devido a conflitos com advogados. Marcelino escreveu sob Valentiniano e Valente e se os regulamentos baixados por esses imperadores sobre a profissão de advogado provam que eles se viram diante de abusos a reprimir resulta, igualmente, das disposições sobre a matéria, que ao tribunal da época não faltaram nem glória nem virtudes.

\section{HONORARIOS DOS ADVOGADOS}

Afirma-se, há séculos, a gratuidade da advocacia entre os antigos romanos, de modo à prática dos honorários introduzir-se muito depois de caída a República, o que fez a assistência do defensor perder o lustro, deixando de ser desinteressada. A advocacia teria degenerado, tornando-se profissão assalariada.

A opinião é errônea em muitos pontos, merecendo retificação. $\mathrm{O}$ ministério do advogado não parece ter sido gratuito nas primeiras épocas de Roma: basta recordarmos o patronato, instituição essencialmente aristocrática. O patrono era senhor de terras e dos poderes públicos. A seu redor agrupava-se primeiro a família natural e depois espécie de família civil, composta de homens cuja fraqueza fazia necessária a existência de proteção. Tais pessoas tornaram-se servidores, cultivando as terras; foram os «colentes», «clientis», «clientes».

Talvez, também, o poder sobre a terra e o político só tivessem, quando da fundação de Roma, sido concedidos à aristocracia em troca de proteção eficaz exercida em favor da classe subordinada. Seja como for, da aliança entre as classes nasceu verdadeiro contrato, cujas leis lhe determinaram os efeitos.

Ora, o primeiro dentre os direitos reconhecidos ao cliente era o de ser defendido em juízo pelo patrono. Tal assistência, porém, estava longe de ser gratuita e em troca desses serviços o cliente se submetia a encargos não tardando em tornar insuportável sua situação.

Os progressos, entretanto, do luxo e a emancipação dos espíritos mudaram os costumes sob o Império dos quais se formara o patronato e os vínculos dessa instituição, baseada em reciprocidade aparente se aprouxaram em conseqüência da abolição progressiva dos privilégios do patriciado de modo ao patrono não tardar em considerar-se livre de suas obrigações. 
A assistência, até então fornecida a título de execução de contrato, passou a ser concedida em vista da conservação de prestígio e de espécie de supremacia honorífica.

O processo, por outro lado, vulgarizou-se sobretudo, vimô-lo, depois das XII Tábuas. Apareceram jurisconsultos plebeus e os antigos encontraram, na defesa de seus interesses, pessoas mais hábeis que as dos patronos. Daí o ministério do advogado («advocatus») termo evocando a idéia d'escolha e de chamado voluntário.

Despojado, assim, do direito exclusivo à assistência judiciária, considerado com razão como um de seus privilégios mais importantes; obrigado a tornar-se advogado ele próprio, aceitando as novas condições de exercício do ministério, o patrono, a princípio, não ousou reclamar salário proibido pela antiga instituição e além do mais humilhante para seu orgulho.

Surgiu, entretanto, entre patrono e cliente a convenção tácita pela qual o último faria ao primeiro um dom a título de remuneração. O jurisconsulto dos primeiros tempos podia dirigir o processo apresentando-se com o título de patrono, em troca dos serviços prestados não exigia salário algum, incompatível com sua qualidade; estipulava, porém, em seu proveito, presente honorífico.

Tal dom ou presente chamou-se, segundo as épocas «honorarium» (sobre o sentido do termo v. D. 11,6,1). «O pretor estabeleceu ação expositiva do fato contra os agrimensores, pelo interesse existente no sentido deles não enganarem em seus relatórios, quando nomeados pelas partes litigantes em ação demarcatória ou por um comprador ou vendedor querendo conhecer a área do imóvel vendido. O pretor foi levado a instituir esta ação pelo fato dos antigos não considerarem a profissão do agrimensor semelhante a mister cujos serviços se alugassem reputando-a, antes, serviço prestado por dever d'amizade de modo a merecer retribuição a título de recompensa chamada por isso honorário. E a tal ponto é assim que se reputa nula a ação de locação proposta contra o agrimensor».

«D. 19,2» Da ação direta e contrária de locação», 38,1 - Paulo, no livro único das «Regras». «Também os advogados não são obrigados a restituir os honorários recebidos se a ação deixou de ser proposta sem culpa deles».

D. 50.13 «Das matérias extraordinárias cujo conhecimento pertence aos presidentes de províncias, bem como das sentenças dos que julgaram mal» 10 - Ulpiano, livro 8 «Sobre todos os Tribunais» (Dos honorários dos advogados).

Fala-se também em «xenium», «solatium», «merces», expressões todas implicando a idéia de oferenda livre e espontânea. Apareceu, mais tarde, o termo "palmarium» indicando um dom de natureza especial oferecido a título de palma ao advogado vencedor. 
Embora desde o III século a.C. o patronato houvesse passado por transformações radicais, as leis de sua instituição permaneceram, pelo menos «pro forma» tendo havido esforços no sentido de preservar na defesa judicial seu caráter aparente de assistência gratuita. Tais esforços permaneceram, porém, infrutíferos pois, dum lado, o patrono não recebia mais do cliente os antigos serviços e, doutro lado, as transformações ocorridas na administração da justiça tinham alterado profundamente a natureza e a extensão das obrigações do advogado perante a parte litigante.

Vem aqui a propósito o exame da lei Cíncia.

No ano 205 a.C. o tribuno da plebe Marco Cíncio Alimento propôs uma lei que foi aprovada e da qual só conhecemos a rubrica: «De donis et muneribus». As doações remuneratórias chamavam-se «munera», donde remuneratória; as demais diziam-se «dona». Proibiria a lei Cíncia os dons e presentes de modo absoluto? Aplicar-se-ia, exclusivamente, aos advogados ou pelo contrário incluí-los-ia em medida geral. Destinar-se-ia tão só a proteger as partes indigentes?

Todas essas questões foram discutidas mas a solução é impossível. Eis a hipótese mais plausível a respeito da lei em seu conjunto: quando, a partir do fim das guerras púnicas, as riquezas se difundiram em Roma o costume de trocar presentes generalizou-se.

Vaidade e cupidez levaram o uso a tais excessos a ponto dos homens sensatos se inquietarem, pois famílias inteiras se arruinavam e os nobres abusavam a ponto de criarem verdadeiro imposto para os plebeus. A lei Cíncia teve por fim especial tentar coibir o abuso. Quando Cíncio apresentou seu projeto certo senador perguntou-lhe ironicamente: «Que pedes, caro Cíncio? «Peço», respondeu o tribuno «que você compre as coisas as quais deseje usar!».

A proibição aplicava-se aos funcionários públicos. Certo Basso, acusado de concussão, defendeu-se sustentando que tivesse apenas recebido presentes. Mas, a lei, escreve Plínio, defensor daquele, proíbe também receber presentes, «Munera quo que accipi vetat».

É também fora de dúvida que a lei visasse os advogados: a lei Cíncia, escreve Tácito, deveu sua origem aos abusos dos advogados.

Parece resultar das fontes fosse intuito do legislador proibir de modo absoluto que funcionários públicos ou pessoas agindo em caráter público recebessem presentes ou honorários em tal qualidade; dizemos isto pois, Cícero, pretendendo observar a lei rigorosamente informa-nos que se julgou autorizado a receber de certo amigo o dom duma biblioteca depois de ter submetido suas dúvidas a Cíncio, descendente do tribuno. Quanto aos advogados a proibição, segundo certos autores, só existia a favor dos clientes pobres, não se aplicando aos honorários exigidos de clientes ricos.

A distinção, porém, deve ser rejeitada. Eis, aliás, os termos prováveis de disposição relativa aos advogados: «Ne quis ob causam 
orandam donum munusve accipiat». Neste particular, entretanto, a lei era anacrônica. Dirigida, contra ${ }^{(*)}$ a «licença» dos advogados, como diz Tácito, ela poderia ter produzido bons resultados.

Incondicional, porém, nas proibições ela só foi respeitada por exíguo número de oradores interessados em ostentar generosidade proveitosa para si próprios. A assistência em juízo se tornara verdadeira profissão exigindo estudos especiais, trabalhos de todos os instantes e a maioria dos advogados continuou a receber remuneração.

A lei não conseguiu nem mesmo reprimir os abusos e em época de esplendor do tribunal romano viu-se Clódio e Curião fixarem seu ministério em porcentagem excessiva. É conhecida a observação sarcástica de Cicero sobre a esfinge de alto preço dada por Verres a Hortênsio, seu defensor.

Marco Licínio Crasso, cuja fortuna segundo Plínio, o Velho se elevava a 76 milhões de francos impunha pactos vergonhosos aos clientes; o próprio Cícero, embora não perdesse ocasião de se vangloriar de respeitador da lei Cíncia e cujos admiradores entusiastas o apontavam como exemplo de desprendimento, o próprio Cícero nem sempre observou os princípios professados.

Não devemos aceitar as acusações atribuídas a Salústio e segundo as quais ele seria advogado penal de mãos ávidas e guela insaciável; mas, existem boas razões de crer que a importância dum milhão de sertércios (duzentos mil francos) recebia por Cícero do ditador Sylla, então acusado, e destinada à compra duma casa, fosse, no todo ou em parte, o preço da assistência do orador; conforme se praticava então, freqüentemente, tal pagamento se dissimulava sob a forma de empréstimo clandestino.

Censurarem-lhe o falso empréstimo, denunciando-se-lhe antecipadamente a destinação. Cícero negou: «se eu comprar essa coisa aceitarei como verdadeira a acusação de ter recebido dinheiro de Sylla». $\mathrm{E}$, de fato, do grande orador acabou comprando a casa; quando seus inimigos em pleno senado o acusaram de mentiroso ele respondeu: «Vós sois singulares personagens; não sabeis deva um bom pai de família ocultar sua intenção de comprar, a fim de evitar a concorrência?»

Como «homo novus» apresentou-se Cícero ao tribunal sem o prestígio do nascimento; o talento, porém, elevou-o logo ao primeiro plano. Notado por Sylla, encarregado de defender os interesses dos maiores personagens de Roma, posto em evidência pelas candidaturas, a demonstração de absoluto desinteresse poderia ser para ele uma especulação lucrativa: excitando a admiração do povo e o reconhecimento da clientela Cícero ganhava sufrágios, pondo assim a juros altos fadigas e trabalhos. Se, entretanto, na posição excepcional da

(*) ... os abusos dos honorários exagerados, contra. etc. 
qual desfrutava, nem sempre se absteve, como parece provável, de receber honorários, não será evidente que advogados menores, exercendo em comparação com Cícero uma profissão sem futuro, cobrassem salários permitindo-lhes viver?

Se, portanto, pelo fato mesmo de existir, a lei Cíncia mostra não fosse gratuito o ministério do advogado por volta da metade do II século a.C. tal situação perdura, no século seguinte.

Tratemos, agora, do meio mais freqüentemente empregado para contornar a lei proibitiva, a saber, as liberalidades testamentárias. A lei proibia ao advogado aceitar presentes da parte mesma, porém não anulava os legados feitos pelo cliente a seu advogado. Os legados dessa espécie foram mesmo considerados honrosos quando não provenientes de fraude ou captação.

Por isso Cícero se vangloriava de ter recebido mais de 20 milhões de sertércios (4 milhões de francos, em legados. É evidente, entretanto, que quando feitas em favor de advogado, como testemunho de apreço e reconhecimento, tais deixas, na maioria dos casos, não passavam da remuneração póstuma de serviços prestados. Tornaram-se, aliás, uma das principais fontes das imensas fortunas precipitando a ruína da República pelo desenvolvimento excessivo das ambições individuais e por sua conseqüência natural, a corrupção.

Dentre os fatos escandalosos causados por esses legados, mesmo antes da desmoralização imperial, existe um, comprometendo altamente dois célebres advogados, contemporâneos de Cícero. Certo Minúcio Basilio, homem riquíssimo, falecera na Grécia e um falsário the atribuiu testamento no qual teve a habilidade de instituir Crasso e Hortênsio como herdeiros, cujo prestígio era então imenso; esperava, assim, garantir a execução do ato fraudulento no qual figurava, naturalmente, como legatário de soma importante: teve êxito, pois os instituídos herdeiros, embora jamais tivessem conhecido o pretenso testador, consentiram em aceitar o fruto de crime evidente.

Nos fins da República as exigências dos advogados não conheceram limites e o patrocínio degenerou em verdadeiro comércio. Augusto tentou refrear o triste estado de coisas: revigorou a lei Cíncia, fazendo o Senado decretar que o advogado contra o qual houvesse prova de ter recebido qualquer retribuição do cliente fosse condenado à restituição do quádruplo.

A medida era detestável pois, se em 154 a.C. não se compreendera que a instituição do patronato deixara de existir na realidade, tendo-se a assistência judiciária já transformado em profissão, merecendo salário honesto, pelo menos as formas republicanas da época permitiam ainda ao orador encontrar, na eleição para os cargos, a recompensa de seus esforços.

Dois séculos mais tarde, porém, quando a autoridade soberana se concentrava nas mãos do príncipe, o advogado viu-se privado de 
perspectiva de remuneração legítima e recorreu à delação para viver e, assim, reforma tentada sem critério tornou-se fonte de nova corrupção.

A avidez, porém, dos advogados, contida um momento, tornou-se ainda mais audaciosa. Sob o reino de Cláudio certo cavaleiro romano, chamado Sâmio pagara 400 mil sertércios (80 mil francos) ao advogado Suilio, seu defensor.

Este último, corrompido por importância maior, aliou-se ao acusador do cliente, o qual desesperado suicidiu-se na casa mesmo do advogado! Indignado diante de tão odiosa prevaricação o Senado exigiu a aplicação da lei Cíncia contra o culpado. Diante do imperador sustentou Suilio a revogação da lei pelo desuso negando pudesse ela aplicar-se-lhe sem retroatividade. Combateu-lhe em seguida as disposições procurando provar que toda profissão deve proporcionar meios de subsistência a quem a exerça. Ora, o advogado deve viver do próprio talento, como da guerra o soldado e da terra o agricultor. Se existiam homens ricos, dando exemplo de desprendimento, era mais freqüente o caso doutros, menos favorecidos pela fortuna, auferindo pingues honorários de suas defesas. Privar, finalmente, o trabalho e o talento de remuneração justa era desencorajá-los e aniquilá-los. Impressionado com essas considerações deixou Cláudio de aplicar a lei Cíncia, limitando-se a exigir que no futuro os advogados não pudessem receber, sob pena de concussão, mais de dez mil sertércios (2.000 francos).

Segundo Tácito esse abrandamento eqüitativo, sancionando pela primeira vez a legitimidade dos honorários, fixando-lhes o máximo em porcentagem moderada, foi rejeitado por Nero, o qual logo no início de seu reinado teria revigorado a lei Cíncia; o anacronismo seria, porém, tão grande que Suetônio parece mais digno de crédito, segundo o qual Nero proibira aos advogados exigirem dos clientes quantia superior à fixada em senatusconsulto o qual obedecia critério moderado.

Tal regimento deve ter tido longa duração, feito, como foi, em época durante a qual os espíritos mais esclarecidos reconheciam a legitimidade dos honorários.

Escreve sobre o assunto Quintiliano: «Seria, por certo, mais digno não vender assistência, parecendo aviltada pelo simples fato de se lhe dar um preço. Se, porém, o advogado não encontra em seu patrimônio meios de subsistência deve-lhe ser permitido tolerar que se lhe reconheça a solicitude. Nessas condições o salário é não só eqüitativo, como, também, necessário e toda a dificuldade se resume em determinar quanto deva o advogado receber».

Segundo Quintiliano os honorários não devem exceder nem os recursos do cliente nem as necessidades de quem os recebe; em suma, convém considerá-los expressão da troca de serviços. 
Os editos de Cláudio e Nero bastavam para conciliar interesses honestos, mas não puderam extirpar os abusos.

Criando, cada dia, necessidades novas, o luxo dava tal atrativo às riquezas a ponto de se aceitarem todos os meios de obtê-las. O escândalo chegou ao auge sob Domiciano, Nerva e Trajano: nessa época dois advogados, Marcello Éprio e Vibio Crispo acumularam, no exercício da profissão, a fortuna de trezentos milhões de sertércios (60 milhões de francos)! Marcial abunda em sarcasmos deixando entrever o grau de desconsideração ao qual baixou em seu tempo a profissão de advogado.

«Queres enriquecer?» pergunta ele: «faz-te advogado!» («Epigramas», $\Pi 1,30$ ). «Se eu quisesse vender minha palavra aos acusados suplices, minha toga ficaria logo suja de dinheiro vindo de todo lado!» (Ibid. V,16).

A certo advogado, antigo padeiro, o poeta censura por ter exigido ao cliente 200 mil sertércios (40 mil francos); a outro o querer absorver, junto com o juiz, quantia superior ao valor da causa (Ibid., II,30 e 30). Segundo o poeta se quisermos ouvir o tinido do dinheiro devemos ir ao «Forum» (Ibid. I,17). Marcial oferece curiosa nomenclatura dos presentes recebidos pelos advogados, chamando-os, «saturnalia», e «natalicia». Eram barras de metal precioso, pano, tapetes, frutas, vinho, pedras preciosas, vasos, estátuas, roupas caras, etc. (IV,46; VII,53; X,87).

Sob Vespasiano, os clientes homenageavam seus advogados oferecendo-lhes o retrato destes últimos. Sobre a venalidade dos advogados, ver Horácio, «Satiras», II,5; Sêneca, «De Ira», II,7; Juvenal, VIII,V,68; Pérsio, III,63 e ss.

Trata-se, é certo, de epigramas; Plínio, entretanto, comprova, mediante fatos, serem eles o retrato fiel do «forum» da época. Eis caso descrito por nosso autor. (in «Cartas», V,4 e 14). Os habitantes de certa localidade italiana (talvez a atual Vicenza) reclamavam no Senado contra o senador Solers (Solerte) o qual pretendia instalar feiras nas terras daqueles e tinham escolhido Nominato como advogado. No dia marcado para o debate Nominato faltou e os clientes se queixaram de terem sido enganados por ele, depois de lhe terem adiantado a importância de 10 mil sertércios (2.000 francos). O pretor Nepos exigiu o comparecimento de Nominato à barra do Senado. $\mathrm{O}$ acusado apresentou-se e foi absolvido, graças a explicações apresentadas com muita habilidade mas foi obrigado a restituir tudo quanto recebera.

Nessa ocasião, porém, Nigrino, tribuno da plebe, leu memorial eloquiente e substancioso queixando-se da venalidade dos advogados, conluiados a peso de ouro com os adversários dos clientes, dos acordos fraudulentos feitos pelos causídicos entre si, de seu ardor em conseguir rendimentos enormes à custa dos cidadãos. Relembrou as anti- 
gas leis sobre o assunto, citou os senatusconsultos e terminou exprimindo a esperança de que o príncipe empregasse os meios destinados a reprimir tamanhos abusos. Dias depois o imperador escreveu ao Senado, em termos severos, porém, moderados, incumbindo-o de tomar as medidas adequadas.

O Senado deliberou e baixou senatusconsulto pelo qual, entre outras disposições, ordenava a todos os litigantes, fosse qual fosse a natureza da causa, que mediante juramento afirmassem nada terem dado, prometido ou feito prometer fosse a quem fosse em razão do processo e antes de iniciado o mesmo. O Senado, proibia também qualquer negócio relativo à defesa, autorizando, entretanto, o advogado a receber até 10 mil sertércios depois do julgamento definitivo da questão. Nepos fez conhecer mediante edito a firme resolução na qual se achava de zelar pelo cumprimento rigoroso do senatusconsulto. Pois bem, coisa estranha! O fato do magistrado foi geralmente reprovado, como se a recomendação do Senado, entregue a si mesma fosse letra morta; censurou-se-lhe a pretensão de inovar, de mostrar excesso de zelo e de se apresentar sem necessidade como reformador dos costumes públicos!

A época de Alexandre Severo foi de florescimento da ciência do direito e o estudo parecia ter apurado os costumes dos advogados, tornados jurisconsultos; o desprendimento que eles então revelaram grangeou-lhes a benevolência do principe, o qual concedeu remuneração condigna àqueles patrocinando gratuitamente.

Admitia-se, entretanto, pudessem os advogados, legitimamente, receber honorários até o máximo de cem moedas de ouro por questão tratada. (D. 50,13,1,12.Ulp.). Decidiu-se, mesmo, expressamente e mediante rescrito, não pudesse a parte repetir aos herdeiros do causídico as quantias a este adiantadas antes da defesa, como dele não tivesse dependido a circunstância da demanda não ser proposta. (D. «Locati», 38,1).

Decretava-se a nulidade de qualquer contrato de honorários feito antes da defesa. Excetuava-se o caso da soma prometida, acrescentada à paga adiantado, não exceder o máximo da taxa permitida (D. 50,h.t.1,12). Na falta de convenção os honorários eram fixados pelo magistrado, considerando-se a importância da causa, o talento do advogado («advocati facundiae») os usos do foro e o grau da instância (D. 50,13,h.t.10).

Rescrito de Constantino (de 326) manda riscar da ordem o advogado que, a título de honorários, recebe ou estipula somas excessivas ou parte determinada da coisa litigiosa («quotalicio» C. «De postulando, 5 ; ibid. «Mandati», 20). Constituição de Valentiniano e Valente (de 368) proíbe, de modo absoluto, qualquer contrato de honorários (C. «De postulando», 6,2) ordenando aos advogados que nada exijam além da soma a eles espontaneamente oferecida. 
Dispõe, ainda, tenham os causídicos a faculdade de falarem quanto quiserem sob a condição de não abusarem em vista do aumento de salário (Ibid. $\S \S 4$ e 5). A promessa de honorários, dissimulada sob a forma de reconhecimento de empréstimo, podia ser anulada até dois anos, depois pela «exceptio non numeratae pecuniae». (Ibid. § 5). Honório e Teodósio assimilaram os honorários ao pecúlio castrense. Justiniano, ordenou fossem eles tributáveis com fundamento em declaração do cliente que os tivesse adiantado (C. «De Judiciis», cost. 13).

Do sobredito podemos concluir: em nenhum tempo, ao contrário do admitido pela opinião comum, o ministério do advogado foi puramente gratuito, pois, nos primeiros tempos de Roma, a assistência do patrono representou compensação, aliás insuficiente, dos serviços prestados pelo cliente; a lei Cíncia, pretendendo exigir do advogado completa renúncia dos mais legítimos interesses, cortando-lhe, por assim dizer as mãos, fora promulgada por ignorância dos verdadeiros caracteres do antigo patronato, do qual restavam então exíguos vestígios; ela nunca foi, aliás, executada rigorosamente como também não o foram os atos legislativos posteriores, tentando revigorar a lei, sem adaptações.

Não se pretende, entretanto, negar a existência de oradores cujos serviços fossem completamente gratuitos. Plínio informa-nos que se absteve de receber qualquer espécie de presente, mesmo a título de estnéia. O escritor se achava, porém, em situação excepcional: de família ilustre, educado por Quintiliano em vista de brilhante futuro, herdeiro do grande nome e da fortuna do tio, chamado a ocupar os mais altos cargos, favorito de Trajano, a advocacia não podia para ele ser profissão. Defendendo gratuitamente postulava a própria causa, pois trabalhava para a própria glória e o salário lhe comprometeria os interesses, em lugar de serví-los. Note-se, aliás, seu cuidado em informar-nos de que, dentre todos os advogados do tempo, era ele o único a compreender assim a própria missão.

Resumindo: durante os três primeiros séculos, desde a fundação de Roma, a profissão de advogado não existiu nem podia existir pois a defesa perante tribunais era «munus» público, imposto pelas instituições a certa classe de pessoas; durante esse período não se podia falar em honorários.

A profissão de advogado resultou da dissolução do patronato, da vulgarização das fórmulas e do desenvolvimento da ciência do direito. Dentre os homens freqüentando o tribunal, a partir dessa época, uns fizeram da atividade forense meio de exercício oratório e meio de obter posição, degrau para subir às magistraturas; outros abraçaram-na como profissão.

Os primeiros patrocinaram, às vezes, gratuitamente, por ambição; os segundos receberam a remuneração do próprio trabalho, sacrificando muitas vezes a honestidade ao desejo de fazer fortuna rápida. Por 
isso, encarando a situação de modo parcial e isolado pode-se dizer, ao mesmo tempo, que a profissão de advogado existiu e não existiu na antiga Roma, que a advocacia foi e não foi gratuita. Cada uma dessas afirmações, verdadeira relativamente, é falsa em sentido absoluto.

\section{PRINCIPAIS FIGURAS DE ADVOGADOS ROMANOS}

Cícero, naturalmente, é o príncipe dos oradores romanos figurando, com Demóstenes, na galeria dos maiores retores da Antigüidade e de todos os tempos. Deixamô-lo de lado, neste momento, pois a envergadura de sua personalidade como orador exigiria estudo especial. O autor da monografia que vimos seguindo, Grellet-Dumazeau não o inclui por isso mesmo na lista dos 54 nomes arrolados, representando em Roma, a oratória forense em diversas épocas. Aliás, a bibliografia atual sobre Cícero em todas as línguas é imensa. Da série apresentada pelo autor francês escolhemos, exemplificativamente, alguns nomes, todos ou quase todos, aliás, citados por Cícero e Quintiliano.

Ei-los: 1. - Marco Pórcio Catão, morto em 149 a.C., cognominado o «Censor» pelo fato de se ter celebrizado pela austeridade no exercício do cargo. Suas defesas, em número superior a cento e cínqüenta e nenhuma das quais chegou até nós, referiam-se a assuntos políticos ligados às suas funções.

2. - Públio Cornélio Cipião Emiliano, o segundo africano, morto em 129 a.C. «Havia nele», diz Cícero, «alta eloqüência, grande integridade, muito sentimento de honra e autoridade igual à do povo romano que recebia dele a sua própria».

3. - Tibério Graco, assassinado em 130 a.C. Filho de Cornélia; sua ação política representa enigma ainda não resolvido. Segundo Cícero ele deveu mais à voz sonora da mãe do que às suas liçóes. Foi grande orador.

4. - Caio Graco, irmão mais moço do precedente, assassinado, também, como o irmão durante sedição que provocara. Caio Graco foi questor e duas vezes tribuno da plebe.

Segundo Cícero sua eloqüência era rica e abundante, o estilo elevado e imponente, o pensamento nobre e sólido.

4. - Caio Sulpício Galba, genro de Crasso, foi bom orador e jurisconsulto. Acusado de ter recebido dinheiro de Jugurta, defendeu-se a si mesmo sendo condenado por meros indícios. A peroração da defesa ficou célebre e segundo Cícero era aprendida de cor pelos jovens destinando-se ao tribunal.

5. - Quinto Lutácio Catulo. Foi cônsul junto com Mário e pereceu, em 87 a.C., por ordem deste. Cícero faz dele um dos interlo- 
cutores de seu diálogo sobre os oradores («De Oratore») e diz: ele discursava com tamanho encanto a ponto de parecer o único a saber falar a língua dos romanos.

6. - Marco Antônio. Morto em 87 a.C. por ordem de Mário, depois de ter ocupado os mais altos cargos. $\mathrm{Na}$ opinião de Cícero, Antônio e Crasso foram os dois mais ilustres oradores do tribunal romano, os primeiros a elevarem a eloqüência latina ao nível do gênio grego.

7. - Públio Sulpício. Rufo, morto em 88 a.C. por ordem de Mário. Cícero considera-o o orador romano, o mais pomposo e o mais trágico de todos quantos ouvira na juventude.

8. - Pompeu, o Grande, morto em 48 a.C., depois de vencido por César. "Meu coetâneo» diz Cícero, «Pompeu nascera para todas as coisas grandes e teria adquirido brilhante glória no tribunal se a ambição não o tivesse impelido para a glória ainda maior dos campos de batalha». O discurso de Pompeu era amplo, a voz era vibrante e a atitude sempre nobre.

9. - Caio-Júlio César. Dentre todos os contemporâneos, César talvez fosse o mais profundo conhecedor da língua latina: falava-a com tanta elegância quanto correção. A voz era forte e sonora, o gesto nobre e todos os movimentos do corpo cheios de majestade. Os principais caracteres da dicção de César eram nitidez, vigor, resolução e sagacidade.

«Se ele se tivesse consagrado exclusivamente ao Tribunal», escreve Quintiliano «nenhum outro nome haveria capaz de ombrear com Cícero». Este último, entretanto, parece ter tido idéia menos elevada de César, advogado, pois diz: «Passemos a César o qual devido à grandeza de seus objetivos e multiplicidade de interesses fez menos pela eloqüência do que seria de esperar de seu gênio divino.» 